\title{
A Response to "The Perspectives of Educators and Learners on E-Learning: A Cross-Sectional Descriptive Study in a Medical School” [Letter]
}

\author{
Safwan Khan (1D) \\ St. George's University of London, \\ London, UK
}

Correspondence: Safwan Khan

Email Safwan-khan@hotmail.com

\section{Dear editor}

I read with great interest the article by Padhi et $\mathrm{al}^{1}$ on the perspectives of educators and learners on E-learning within medical school. As a final-year medical student having experienced significant E-learning due to the COVID-19 pandemic, I wish to offer my insights and suggest aspects of the study that could be improved.

Padhi et al $^{1}$ concluded more than half of students were satisfied with E-learning and perceived it to be effective. A similar study by Gupta et $\mathrm{al}^{2}$ overwhelmingly showed students found online classes to be useful. However, due to the nature of lockdown, E-learning is the only form of teaching students can receive and the perceived benefit may be greater than the actual. Therefore, to quantify the benefit Padhi et al could have set students a short curriculum-based online exam prior to and after the month of teaching, alongside the questionnaire. This would have yielded a better representation of the effectiveness of online teaching for the students.

In addition, Padhi et al ${ }^{1}$ failed to categorise medical students into subsets in the study in accordance with their year of education. There is a greater emphasis on clinical skills and patient interaction for the later years, and it would have been illuminating to see how older students specifically felt about online teaching. Padhi et $\mathrm{al}^{1}$ could have also asked direct questions about the impact of online learning on students' perceived clinical skills and confidence with patient interaction. In a study by Dost et $\mathrm{al}^{3}{ }^{3} 76 \%$ of the students felt online teaching had not successfully replaced the clinical teaching they received via direct patient contact and $82 \%$ stated they cannot learn practical clinical skills through online teaching. This led to a low score for being "well prepared for my profession", showing clinical confidence is affected with online teaching methods.

Both learner and educator dissatisfaction with E-learning was largely due to network issues and technological barriers, similar to other studies. ${ }^{2,3}$ In the study by Padhi et al, ${ }^{1}$ many were using online platforms for the first time, and the problems faced could be down to beginner error. Therefore, an additional longitudinal study over several months assessing these factors would be useful with the expectation these issues will resolve as the participants become more familiar with E-learning. Further, a solution suggested was to provide video recordings of lectures so students can go through them in their own time. This has proven to be an effective 
method for learning, in addition to being convenient and stress relieving. ${ }^{4}$ However, $50 \%$ of the learners cited lack of adequate interaction as a problem with E-learning and Padhi et $\mathrm{al}^{1}$ failed to explore solutions to this in the questionnaire. For example, asking learners how they feel about online small group tutorials with fewer numbers or time slots where students can interact one to one with a tutor and ask direct questions.

In conclusion, Padhi et $\mathrm{al}^{1}$ should be commended for exploring the intricacies of E-learning for educators and learners, and the study presented several important findings that can be applied to improve online medical education. It would have been of benefit to assess clinical knowledge through exam testing and focus on the impact on clinical skills learning within the questionnaire.

\section{References}

1. Padhi KS, Balmuchu G, Acharya PS, Singh SR, Joseph T. The perspectives of educators and learners on E-learning: a cross-sectional descriptive study in a medical school. Adv Med Educ Pract. 2021;12:1059-1066. doi:10.2147/AMEP.S326147

2. Gupta S, Dabas A, Swarnim S, Mishra D. Medical education during COVID-19 associated lockdown: faculty and students' perspective. Med J Armed Forces India. 2021;77(Suppl 1):S79-S84. doi:10.1016/ j.mjafi.2020.12.008

3. Dost S, Hossain A, Shehab M, Abdelwahed A, Al-Nusair L. Perceptions of medical students towards online teaching during the COVID-19 pandemic: a national cross-sectional survey of $2721 \mathrm{UK}$ medical students. BMJ Open. 2020;10(11):e042378. doi:10.1136/ bmjopen-2020-042378

4. Nimavat N, Singh S, Fichadiya N, et al. Online medical education in India - different challenges and probable solutions in the age of COVID-19. Adv Med Educ Pract. 2021;12:237-243. doi:10.2147/ AMEP.S295728

\title{
Disclosure
}

The author reports no conflicts of interest in this communication.

\begin{abstract}
Dove Medical Press encourages responsible, free and frank academic debate. The content of the Advances in Medical Education and Practice 'letters to the editor' section does not necessarily represent the views of Dove Medical Press, its officers, agents, employees, related entities or the Advances in Medical Education and Practice editors. While all reasonable steps have been taken to confirm the content of each letter, Dove Medical Press accepts no liability in respect of the content of any letter, nor is it responsible for the content and accuracy of any letter to the editor.
\end{abstract}

\section{Publish your work in this journal}

Advances in Medical Education and Practice is an international, peerreviewed, open access journal that aims to present and publish research on Medical Education covering medical, dental, nursing and allied health care professional education. The journal covers undergraduate education, postgraduate training and continuing medical education including emerging trends and innovative models linking education, research, and health care services. The manuscript management system is completely online and includes a very quick and fair peer-review system. Visit http://www.dovepress.com/testimonials.php to read real quotes from published authors. 